\title{
Irrigation and fertigation scheduling under drip irrigation for maize crop in sandy soil
}

\author{
Mahmoud M. Ibrahim ${ }^{1 *}$, Ahmed A. El-Baroudy ${ }^{1}$, and Ahmed M. Taha \\ ${ }^{1}$ Department of Soil Water, Tanta University, 31527 Tanta, Egypt \\ ${ }^{2}$ Department of Water Requirements and Field Irrigation, Institute of Soil, Water and Environment, ARC, Al-Giza, Egypt
}

Received January 10, 2015; accepted November 27, 2015

\begin{abstract}
A b s t r a c t. Field experiments was conducted to determine the best irrigation scheduling and the proper period for injecting fertilizers through drip irrigation water in a sandy soil to optimize maize yield and water productivity. Four irrigation levels (0.6, $0.8,1.0$ and 1.2) of the crop evapotranspiration and two fertigation periods (applying the recommended fertilizer dose in 60 and $80 \%$ of the irrigation time) were applied in a split-plot design, in addition to a control treatment which represented conventional irrigation and fertilization of maize in the studied area. The results showed that increasing the irrigation water amount and the fertilizer application period increased vegetative growth and yield. The highest grain yield and the lowest one were obtained under the treatment at 1.2 and of 0.6 crop evapotranspiration, respectively. The treatment at 0.8 crop evapotranspiration with fertilizer application in $80 \%$ of the irrigation time gave the highest water productivity $\left(1.631 \mathrm{~kg} \mathrm{~m}^{-3}\right)$ and saved $27 \%$ of the irrigation water compared to the control treatment. Therefore, this treatment is recommended to irrigate maize crops because of the water scarcity conditions of the studied area.
\end{abstract}

$\mathrm{K}$ e y w o r d s: fertigation, sandy soil, drip irrigation, water productivity, maize yield

\section{INTRODUCTION}

Fertigation is the addition of fertilizers through irrigation water. It is particularly important for irrigated agriculture in sandy soils where large quantities of fertilizers should be applied to meet crop requirements and to prevent loss by leaching. Fertigation has been found as one of the best ways for applying water and nutrients through the drip irrigation system. It has been reported by several researchers (Deshmukh and Hardaha, 2014; El-Hendawy et al.,

*Corresponding author e-mail: mahmoudibrahim421@yahoo.com
2008; Feleafel and Mirdad, 2013; and Vijayakumar et al., 2010) that the drip irrigation system has many advantages. It saves water, machinery and labour, application of fertilizers is more accurate and uniform, and nutrient uptake by roots is improved. Drip irrigation proves its superiority over other methods of irrigation due to the direct application of water and nutrients in the vicinity of the root zone. Abd El-Wahed and Ali (2013) showed that the drip irrigation system maximized maize grain yield and water use efficiency compared to the sprinkler irrigation system. The highest values of grain yield and water use efficiency were recorded for plants irrigated with $100 \%$ of the crop evapotranspiration (Etc). El-Meseery (2003) found that drip irrigation for maize in sandy soil saved about 20 to $25 \%$ of the water used by applying 80 and $75 \%$ of the Etc, respectively, and no significant difference in crop yield was observed in comparison to crop yield at application of $100 \%$ of Etc. Additionally, there was an increase in the water use efficiency by $6 \%$. AbdEl-Hafez et al. (2001) revealed that the drip irrigation method increased field and crop water use efficiency of maize crops in clay soil by 35 and $9.52 \%$, respectively, as compared to furrow irrigation. The mean values of water application efficiency and the percentage of percolation losses for the drip irrigation system were 93.25 and $6.75 \%$, respectively. In turn, the mean values for the furrow irrigation method were 76.4 and $23.6 \%$, respectively.

(C) 2016 Institute of Agrophysics, Polish Academy of Sciences 
Maize (Zea mays) is one of the most important cereals for both human and animal consumption. It is planted for grain and forage. In terms of global production, maize is the third most important food crop after rice and wheat (USDA, 2011). The demand for maize is increased as both fresh and processed food. The greatest challenge for the agricultural sector is to produce more yields from less water ie maximizing water productivity (WP). This could be achieved by proper irrigation scheduling and application of fertilizers through the irrigation water (fertigation) using the drip irrigation system. Extensive research has been undertaken in order to investigate WP. Zwart and Bastiaansen (2004), for example, reported values of 1.1-2.7 $\mathrm{kg} \mathrm{m}^{-3}$ for the WP of maize. The varying range they reported was attributed to factors such as climate, irrigation practices, and the application of fertilizers. Their findings suggest that decreasing irrigation application is the key for improving WP. Moayeri et al. (2011) reported a low value of $1.01 \mathrm{~kg} \mathrm{~m}^{-3}$ for maize WP in Iran. They indicated that the most important cause of the low WP was farmers inadequate knowledge about irrigation, plant nutrient deficiencies, and improper crop management practices.

On other hand, water is a vital source for crop production and its resources are limited in Egypt. The per capita share of fresh water resources is now below $800 \mathrm{~m}^{3}$ per person and it is expected to decrease to $350 \mathrm{~m}^{3}$ per person by 2025 when the number of population increases to 100 million. About $84 \%$ of water resources are consumed by the agricultural sector (El-Beltagy and Abo-Hadeed, 2008). One way to maximize the use of this limited resource is to improve water management techniques and use proper and more efficient irrigation systems such as the drip irrigation system, particularly in newly reclaimed sandy soils (AbuZeid, 1999).
Therefore, the first aim of this study is to determine the best irrigation scheduling and the proper period for injecting fertilizers through the irrigation water, which can optimize the maize crop yield. The second aim is to enhance the water productivity of maize in the sandy soils under the drip irrigation in Egypt.

\section{MATERIALS AND METHODS}

Two field experiments were conducted at AlyMobarak experimental farm in the South Tahrir Research station, Egypt, during the growing seasons of 2009 and 2010. The experimental site was a newly reclaimed sandy soil of the El-Bustan area in the west of the Nile delta. It is situated at an altitude of $6.7 \mathrm{~m}$ above the mean sea level and is intersected by $31^{\circ} 02^{-} \mathrm{N}$ latitude and $30^{\circ} 28^{-} \mathrm{E}$ longitude. The weather is hot with no rain from May to October, and with a mean air temperature exceeding $27^{\circ} \mathrm{C}$ and mean relative humidity of about $70 \%$ during daytime in these months. In winter, the weather is usually cold with a mean air temperature of about $16^{\circ} \mathrm{C}$. The scarce amounts of water coming from rainfall do not contribute to water requirements of winter crops. The weather data for the experimental site during the growing seasons of 2009 and 2010 are presented in Table 1.

The soil of the experimental area is sandy in texture (90.5\% sand, $3.85 \%$ silt, and $5.65 \%$ clay) with an average bulk density of $1.67 \mathrm{Mg} \mathrm{m}^{3}$ for $0-60 \mathrm{~cm}$ depth and is alkaline in reaction with $\mathrm{pH}$ values ranging from 9.13 to 9.38 . Average soil salinity expressed as soil electrical conductivity (EC) in the saturated soil paste extract and organic matter content over $60 \mathrm{~cm}$ depth were about $0.33 \mathrm{dS} \mathrm{m}^{1}$ and $0.12 \%$, respectively. Field capacity, wilting point, and available water values were $10.3,5.02$, and $5.28 \%$, respectively. The available macronutrient values $\mathrm{N}, \mathrm{P}$, and $\mathrm{K}$ were $15.10,4.85$, and $60.75 \mathrm{mg} \mathrm{kg}^{-1}$. Chemical and physical soil analyses were conducted by the standard methods as

T a b l e 1. Monthly mean: minimum (Tmin) and maximum (Tmax) temperature, relative humidity (RH), and pan evaporation (Ep) at the experimental site in the 2009 and 2010 growing seasons

\begin{tabular}{|c|c|c|c|c|c|c|c|c|c|c|}
\hline \multirow[t]{2}{*}{ Month } & $\begin{array}{c}\text { Ep } \\
\left(\mathrm{mm} \mathrm{day}^{-1}\right)\end{array}$ & $\begin{array}{l}\text { Sunshine } \\
\text { duration } \\
\text { (h) }\end{array}$ & $\begin{array}{l}\mathrm{RH} \\
(\%)\end{array}$ & $\begin{array}{l}\text { Tmin } \\
\left({ }^{\circ} \mathrm{C}\right)\end{array}$ & $\begin{array}{c}\text { Tmax } \\
\left({ }^{\circ} \mathrm{C}\right)\end{array}$ & $\begin{array}{c}\text { Ep } \\
\left(\mathrm{mm} \mathrm{day}^{-1}\right)\end{array}$ & $\begin{array}{l}\text { Sunshine } \\
\text { duration } \\
\text { (h) }\end{array}$ & $\begin{array}{l}\mathrm{RH} \\
(\%)\end{array}$ & $\begin{array}{l}\text { Tmin } \\
\left({ }^{\circ} \mathrm{C}\right)\end{array}$ & $\begin{array}{l}\text { Tmax } \\
\left({ }^{\circ} \mathrm{C}\right)\end{array}$ \\
\hline & \multicolumn{5}{|c|}{ Season 2009} & \multicolumn{5}{|c|}{ Season 2010} \\
\hline May & 3.95 & 13.6 & 68 & 18.6 & 31.8 & 5.4 & 13.6 & 60 & 17.6 & 30.7 \\
\hline June & 5.87 & 14.0 & 65 & 17.7 & 31.6 & 6.5 & 14.0 & 61 & 17.9 & 32.5 \\
\hline July & 6.36 & 13.8 & 73 & 22.0 & 37.1 & 5.9 & 13.8 & 74 & 21 & 36.7 \\
\hline August & 7.25 & 13.2 & 68 & 18.2 & 32.5 & 8.2 & 13.2 & 77 & 19.8 & 34.7 \\
\hline September & 6.43 & 12.2 & 69 & 19.4 & 34.2 & 6.5 & 12.2 & 71 & 18.5 & 33.6 \\
\hline October & 5.97 & 11.3 & 64 & 21.0 & 29.3 & 6.3 & 11.3 & 71 & 19.9 & 29.2 \\
\hline
\end{tabular}


described by Tan (1996). Chemical analysis of the irrigation water indicated that electrical conductivity was 0.50 $\mathrm{dS} \mathrm{m}^{-1}$ at $25^{\circ} \mathrm{C}$ and the $\mathrm{pH}$ value was 7.55 .

The experiments were laid out in a split-plot design with four replicates. Each plot area was $140 \mathrm{~m}^{2}(20 \times 7 \mathrm{~m})$. The main plots were designed for the irrigation treatments and the sub-plots were assigned to the fertigation treatments. The irrigation treatments $(I)$ comprised four irrigation water amounts ie $0.6\left(I_{1}\right), 0.8\left(I_{2}\right), 1.0\left(I_{3}\right)$, and $1.2\left(I_{4}\right)$ of the crop evapotranspiration $($ Etc $)$. In addition, in the control treatment (conventional irrigation) represented the traditional irrigation in the studied area, in which maize is irrigated every 3 days by the drip irrigation method for an irrigation time of about $5 \mathrm{~h} \mathrm{ha}^{-1}$, depending on the growers experience, with fertilizer application manually side-dressed on the field. This method results in a total amount of applied water of 7230 and $8410 \mathrm{~m}^{-3} \mathrm{~h}^{-1}$ in 2009 and 2010, respectively.

The fertigation treatments consisted in two periods of fertilizer application through the irrigation water, namely the application of the recommended fertilizer dose for periods equal to 80 and $60 \%$ of the irrigation time. Fertilizers should not be added to irrigation water at the very beginning of irrigation to ensure the stability of water pressure and discharges. This maintains high efficiency and equality in water and fertilizer distribution for each plant. Similarly, at the end of irrigation, some short time should be also left without injecting any fertilizers to leach any remaining deposits from the dippers to evade any possible closures.

The maize crop (hybrid SC10) was planted on the 30th of May 2009 and 2010, and was harvested on the 3rd of October 2009 and 2010. Plant density was seven plants per square meter, which is appropriate to sandy soil. Irrigation water was applied every three days by using surface drip lateral lines connected to the sub-main line. Each lateral line is $20.0 \mathrm{~m}$ long and spaced at $0.7 \mathrm{~m}$ on the sub-main and is equipped with build-in emitters of a $21 \mathrm{~h}^{-1}$ discharge rate spaced at $0.3 \mathrm{~m}$ on the lateral lines. A differential pressure tank was connected to the drip irrigation system to inject all fertilizer via irrigation. Nitrogen fertilizer was added in the form of ammonium nitrate at the rate of $318 \mathrm{~kg} \mathrm{~N} \mathrm{ha}^{-1}$. Potassium sulphate was added at the rate of $120 \mathrm{~kg} \mathrm{~K} \mathrm{ha}^{-1}$. Phosphorous fertilizer was added at the rate of $55 \mathrm{~kg} \mathrm{P} \mathrm{ha}^{-1}$. Micronutrients ie $\mathrm{Fe}, \mathrm{Zn}$, and $\mathrm{Mn}$ were also added at the rate of 238:238:238 $\mathrm{g} \mathrm{ha}^{-1}$.

The amount of the irrigation water applied $(\mathrm{Wa})$ through drip irrigation per treatment was calculated by the following formula:

$$
W a=\frac{I E t c}{E a}+L R,
$$

where: $I$ - empirical irrigation level $(0.6,0.8,1.0$, and 1.2 of Etc, respectively, for treatments $I_{1}, I_{2}, I_{3}$, and $\left.I_{4}\right), E t c-$ crop evapotranspiration, $E a$ - irrigation efficiency of the drip system, determined at the beginning of each season as 0.80 and $L R$ - leaching requirements ( $20 \%$ of the calculated irrigation water was additionally applied per irrigation during the growing seasons for leaching purposes).

Crop evapotranspiration $(E t c)$ was calculated according to Allen et al. (1998), using the equation:

$$
E t c=E T o K c,
$$

where: $E T o$ - reference crop evapotranspiration and $K c-$ crop coefficient. The recommended values of $K c$ for maize crops were used according to Allen et al. (1998).

The reference crop evapotranspiration (ETo) was calculated by the following formula:

$$
E T o=E p K p,
$$

where: $E p$ - the cumulative evaporation amount for considering the irrigation interval, $K p$ - evaporation pan coefficient (the $K p$ value used for the experimental site is 0.75 ). Evaporation data were collected daily from a standard class A pan evaporation tank located near the experimental field.

Irrigation time was calculated according to the equation:

$$
t=\frac{W a A}{q},
$$

where: $t$ - irrigation time (h), $W a-$ depth of applied irrigation water $(\mathrm{mm}), A$ - wetted area by emitters $\left(\mathrm{m}^{2}\right), q$ - emitter discharge $\left(1 \mathrm{~h}^{-1}\right)$.

Irrigation water productivity (WP) was determined to evaluate the benefit of the applied water through economic crop production. It can be defined as the amount of grain yield a cubic meter of water may produce. The values of WP $\left(\mathrm{kg} \mathrm{m}^{-3}\right)$ were determined by dividing grain yield $\left(\mathrm{kg} \mathrm{ha}^{-1}\right)$ by total applied irrigation water $\left(\mathrm{m}^{3} \mathrm{ha}^{-1}\right)$ according to Ali et al. (2007).

Samples of four plants were taken after 105 days from the planting date for each subplot randomly in all replicates and the following measurements were made:

- plant height $(\mathrm{cm})$ from the soil surface,

- the maximum leaf area was measured and the leaf area index $(L A I)$ was calculated by the following equation:

$$
L A I=\frac{\text { leaf area per plant }}{\text { plant ground }},
$$

where: plant ground area is the area of land occupied by the plant (equal distance between the plant $\times$ distance between the ridges).

Four plants were selected randomly from each plot to estimate the yield components. The straw yield and the grain yield $\left(\mathrm{t} \mathrm{ha}^{-1}\right)$ were calculated from the yield of the whole plot. The data recorded at harvest were as follows: (a) ear length (cm), (b) number of grain ear ${ }^{-1}$, (c) 100 grain weight $(\mathrm{d})$, and grain yield $\left(\mathrm{t} \mathrm{ha}^{-1}\right)$ adjusted at $15.50 \%$ moisture content. 
Data were analyzed using analysis of variance (ANOVA). Comparisons between average values from the different treatments were made by LSD test at a 0.05 probability significance level (Steel and Torrie, 1984).

\section{RESULTS AND DISCUSSION}

The studied vegetative growth, plant height, and leaf area index was significantly affected by the irrigation application rates $(\mathrm{p}<0.05)$ (Table 2). The highest values over the two seasons were recorded when plants were irrigated at 1.2 Etc, while the lowest ones were obtained when plants received irrigation at 0.6 Etc. The average values of the plant height and leaf area index over the two seasons were higher by about $25 \%$ under the treatment at 1.2 Etc than that at 0.6 Etc. This could be attributed to the increase in the activity as a result of good absorption of nutrients with a high level of available moisture (El-Kalla et al., 1985).
The data also showed that the plant height and leaf area index had significantly higher values $(p<0.05)$ under the conventional irrigation than that under the irrigation scheduling treatments at $0.6,0.8$, and 1.0 Etc. However, the difference between conventional irrigation and irrigation scheduling at 1.2 Etc was not significant $(\mathrm{p}<0.05)$. These results may be due to the higher amount of the water applied under the conventional irrigation and the 1.2 Etc treatments than that applied under the other treatments, which leads to improved availability and absorption of the nutrient elements. It has been observed that even when higher amounts of nutrients are present in the soil, crops cannot absorb or utilize nutrients properly and optimally if water supply becomes inadequate (Majumder, 2002). The grown plants may also be stressed under the treatments at $0.6,0.8$, and 1.0 Etc due to insufficient water supply. Maize crop is sensitive to both moisture stress and excessive moisture

T a b l e 2. Vegetation growth traits affected by fertigation and irrigation treatments

\begin{tabular}{|c|c|c|c|c|c|c|c|c|}
\hline \multirow{3}{*}{$\begin{array}{l}\text { Irrigation } \\
\text { treatment } \\
(I)\end{array}$} & \multicolumn{8}{|c|}{ Fertigation treatment $(\mathrm{F})$} \\
\hline & \multicolumn{4}{|c|}{ Season 2009} & \multicolumn{4}{|c|}{ Season 2010} \\
\hline & F test & Mean & $60 \%$ & $80 \%$ & F test & Mean & $60 \%$ & $80 \%$ \\
\hline \multicolumn{9}{|c|}{ Plant height } \\
\hline $\begin{array}{l}\text { Conventional } \\
\text { irrigation }\end{array}$ & & 230 & \multicolumn{2}{|c|}{ Side dressed } & & 226 & \multicolumn{2}{|c|}{ Side dressed } \\
\hline 0.6 Etc & & 172.5 & 170.0 & 175.0 & & 175.0 & 173.0 & 178.0 \\
\hline $0.8 E t c$ & & 184.0 & 178.0 & 190.0 & & 189.5 & 182.0 & 197.0 \\
\hline $1.0 \mathrm{Etc}$ & $\mathrm{LSD}=10.55$ & 188.5 & 186.0 & 191.0 & $\mathrm{LSD}=11.52$ & 195.0 & 190.0 & 200.0 \\
\hline $1.2 \mathrm{Etc}$ & & 217.5 & 210.0 & 225.0 & & 217.0 & 214.0 & 220.0 \\
\hline Mean & & & 186.0 & 195.2 & & & 189.7 & 198.7 \\
\hline LSD & & & 8.504 & & & & 6.562 & \\
\hline$I^{*} \mathrm{~F}$ & & & NS & & & & NS & \\
\hline \multicolumn{9}{|c|}{ Leaf area index } \\
\hline $\begin{array}{l}\text { Conventional } \\
\text { irrigation }\end{array}$ & & 5.0 & \multicolumn{2}{|c|}{ Side dressed } & & 5.1 & \multicolumn{2}{|c|}{ Side dressed } \\
\hline 0.6 Etc & & 3.85 & 3.79 & 3.90 & & 3.98 & 3.80 & 4.15 \\
\hline $0.8 E t c$ & & 3.99 & 3.86 & 4.11 & & 4.73 & 4.25 & 5.20 \\
\hline 1.0 Etc & LSD $=0.41$ & 4.40 & 4.11 & 4.70 & LSD $=0.407$ & 4.80 & 4.30 & 4.90 \\
\hline $1.2 \mathrm{Etc}$ & & 4.77 & 4.72 & 4.81 & & 5.03 & 4.75 & 5.30 \\
\hline Mean & & & 4.12 & 4.38 & & & 4.25 & 4.99 \\
\hline LSD & & & 0.406 & & & & 0.405 & \\
\hline$I^{*} \mathrm{~F}$ & & & NS & & & & NS & \\
\hline
\end{tabular}

NS - not significant. 
(Doorenbos and Kassam, 1979). Excess moisture is harmful to crops, and the water stress at flowering and seed formation stages reduces the crop yield. Otegui et al. (1995), Pandey et al. (2000) and El Nady and Borham (2009) found that maize is particularly sensitive to water and other environmental stresses around flowering.

The vegetative growth traits were also significantly affected by the fertigation application rates $(\mathrm{p}<0.05)$. The results in Table 2 indicate that the increasing fertigation period increased the plant height and leaf area index significantly. The average values of the plant height and leaf area index over the two seasons were increased significantly by about 5 and $16 \%$, respectively, with application of the recommended fertilizer dose in $80 \%$ of the irrigation time, compared to that in $60 \%$ of the irrigation time. This may be caused by the fact that the application of the fertilizer dose in $80 \%$ of the irrigation time reduced nutrient leaching from the root zone and increased its absorption by the growing plants, compared to the application of the recommended fertilizer dose in $60 \%$ of the irrigation time. These results are in harmony with those obtained by Lamm et al. (2001) and by Papadopoulos (1995), who stated that under the drip fertigation system an uptake of the $\mathrm{N}$ fertilizer exceeding $80 \%$ was obtained with the same amount of water compared to conventional soil $\mathrm{N}$ fertilization, where the $\mathrm{N}$ utilization efficiency rarely exceeds $50 \%$ even under good irrigation scheduling. The interaction effect of irrigation and fertigation treatments did not show any significant effect on the studied vegetative growth traits in the two years of study. However, the values of the studied vegetative growth parameters were slightly higher in 2010 than those in 2009 as a result of better weather conditions prevailing in 2010 .

The average values over the two seasons of the yield components, namely ear length, number of grains ear ${ }^{-1}$, and 100 grain weight were significantly increased with the increasing irrigation amount from 0.6 to 1.2 Etc (Table 3). The treatment at 1.2 Etc increased ear length by $25.7 \%$, number of grain/ear by $27.6 \%$, and 100 grain weight by $31.1 \%$, compared to treatment at 0.6 Etc. The different yield components were also significantly affected by the fertigation period treatments (Table 3 ). These trends were similar in the two growing seasons. When the fertilizer application period was reduced from 80 to $60 \%$ of the irrigation time, a reduction in all yield components was noticed. The reduction percentages over the two seasons were about 14.6, 11.1 , and $8.6 \%$ for ear length, number of grain ear ${ }^{-1}$, and 100 grain weight, respectively.

The maize grain yield increased significantly with the increasing irrigation water amount from 0.6 to 1.2 Etc (Table 3). Irrigation of maize plants at 1.2 Etc increased grain yield by about $18.7,23.0$, and $97.0 \%$, as an average for the two seasons, compared to irrigation at 1.0, 0.8, and 0.6 Etc, respectively. The highest grain yield over the two seasons $\left(7.98 \mathrm{tha}^{-1}\right)$ was produced at irrigation at $1.2 \mathrm{Etc}$, while the lowest one $\left(4.05 \mathrm{t} \mathrm{ha}^{-1}\right)$ was obtained at 0.6 Etc. Grain yield was also influenced positively and significantly by the fertilizer application period. Fertigation in $80 \%$ of the irrigation time increased the average grain yield by $5.7 \%$, compared to that in $60 \%$ of irrigation time. Grain yield and yield component differed significantly under the different irrigation scheduling, compared to the control treatment. The highest grain yield under the treatment at 1.2 Etc exceeded that of the conventional irrigation (the control treatment) by about $6.7 \%$. This may be due to the leaching of nutrients away from the root zone as a result of the increasing amount of the irrigation water applied under the conventional irrigation, which produced low yield, as shown in Table 4. Meanwhile, the treatment at 0.6 Etc resulted in the lowest grain yield and exhibited a $46.4 \%$ decrement in the grain yield, compared to the control treatment. This means that the grown plants may be stressed under the treatment at 0.6 Etc due to insufficient water supply.

The interaction between the irrigation and fertigation treatments was significant in the two seasons, except for ear length and 100 grain weight, and for the grain yield in the first season only. The highest values of the grain yield and yield components were obtained when maize was irrigated at 1.2 of Etc and at fertigation application in $80 \%$ of the irrigation time. This may be related to the fact that application of the fertilizer dose in $80 \%$ of the irrigation time provides excellent uniformity of fertilizer application, reduces nutrient leaching, and supplies the growing plants with the necessary nutrients. In addition, the high amount of the irrigation water applied under the treatment at 1.2 Etc resulted in more available soil moisture in the root zone, which induced greater accessibility of nutrients to be absorbed by plant roots; this was positively reflected in the yield and yield components. The ideal conditions for maize growth require high and nearly constant soil water potential, particularly during flowering and pollination stages ( $\mathrm{Ne}$ Smith and Ritchie, 1992; Stone et al., 2001). The results obtained were in agreement with those of El-Gindy et al. (2003), who indicated that the highest average grain yield and yield components were achieved from the highest irrigation level, and with those of El-Hendawy (2008), who reported that drip irrigation frequency once every 2 or 3 days with nitrogen fertigation was recommended to maximize the maize yield grown in sandy soil under the Egyptian conditions.

The highest irrigation water amount applied $\left(7820 \mathrm{~m}^{3}\right.$ $\mathrm{ha}^{-1}$ ), averaged over the two seasons, was obtained under the conventional treatment, compared with other irrigation treatments in both growing seasons (Table 4). Meanwhile, the applied water under the irrigation scheduling treatments at 0.6, 0.8, 1.0, and 1.2 Etc varied between 3430 and $5655 \mathrm{~m}^{3} \mathrm{ha}^{-1}$, an average of 2 seasons, respectively. This was expected since the irrigation scheduling procedure was planned with regard to the crop and weather conditions, whereas the conventional irrigation depends on visual inaccurate indicators. The seasonal amount of water applied 
T a b l e 3. Yield and yield components of maize with different irrigation levels under drip irrigation and fertigation treatments in a sandy soil

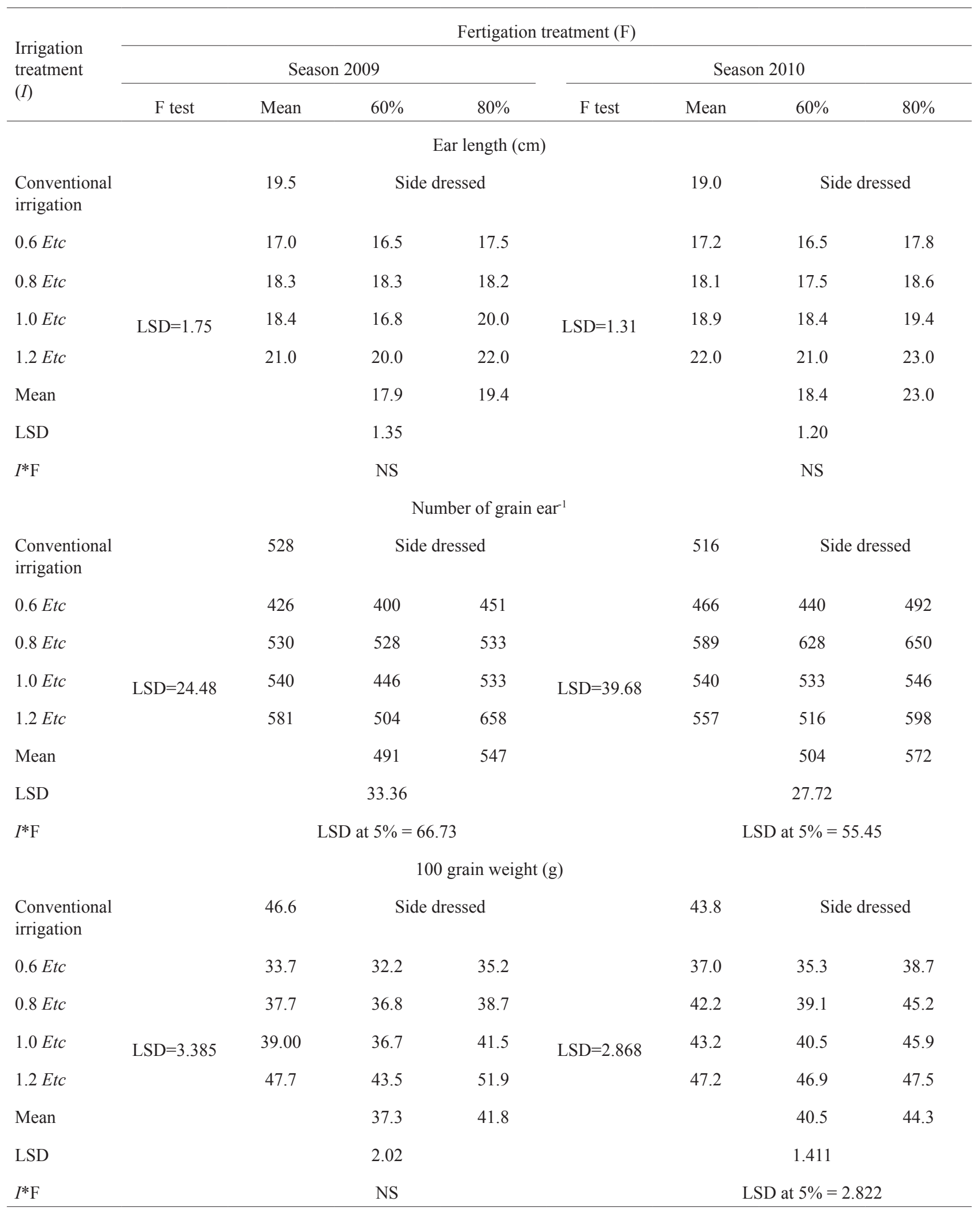

NS - not significant. 
T a b l e 3. Continuation

\begin{tabular}{|c|c|c|c|c|c|c|c|c|}
\hline \multirow{3}{*}{$\begin{array}{l}\text { Irrigation } \\
\text { treatment } \\
\text { (I) }\end{array}$} & \multicolumn{8}{|c|}{ Fertigation treatment $(\mathrm{F})$} \\
\hline & \multicolumn{4}{|c|}{ Season 2009} & \multicolumn{4}{|c|}{ Season 2010} \\
\hline & F test & Mean & $60 \%$ & $80 \%$ & F test & Mean & $60 \%$ & $80 \%$ \\
\hline \multicolumn{9}{|c|}{ Grain yield $\left(\mathrm{t} \mathrm{ha}{ }^{-1}\right)$} \\
\hline $\begin{array}{l}\text { Conventional } \\
\text { irrigation }\end{array}$ & & 7.88 & \multicolumn{2}{|c|}{ Side dressed } & & 7.09 & \multicolumn{2}{|c|}{ Side dressed } \\
\hline 0.6 Etc & & 3.86 & 3.85 & 3.88 & & 4.25 & 4.23 & 4.26 \\
\hline 0.8 Etc & & 6.44 & 3.36 & 6.52 & & 6.54 & 5.93 & 7.16 \\
\hline $1.0 \mathrm{Etc}$ & $\mathrm{LSD}=1.443$ & 6.55 & 6.49 & 6.61 & $\mathrm{LSD}=0.644$ & 6.89 & 6.52 & 7.26 \\
\hline 1.2 Etc & & 8.57 & 8.42 & 8.56 & & 7.39 & 7.33 & 7.46 \\
\hline Mean & & & 6.20 & 6.40 & & & 6.00 & 6.50 \\
\hline LSD & & & 0.194 & & & & 0.511 & \\
\hline$I^{*} \mathrm{~F}$ & & & NS & & & & t $5 \%=$ & \\
\hline
\end{tabular}

NS - not significant.

T a b l e 4. Applied water and water productivity for maize crops in 2009 and 2010 seasons

\begin{tabular}{|c|c|c|c|c|c|c|}
\hline \multirow{3}{*}{$\begin{array}{l}\text { Irrigation } \\
\text { treatment } \\
(I)\end{array}$} & \multicolumn{3}{|c|}{ Water productivity $\left(\mathrm{kg} \mathrm{m}^{-3}\right)$} & \multicolumn{3}{|c|}{ Applied water $\left(\mathrm{m}^{3} \mathrm{ha}^{-1}\right)$} \\
\hline & \multicolumn{6}{|c|}{ Fertigation treatment $(\mathrm{F})$} \\
\hline & Mean & $60 \%$ & $80 \%$ & Mean & $60 \%$ & $80 \%$ \\
\hline \multicolumn{7}{|c|}{ Season 2009} \\
\hline $\begin{array}{l}\text { Conventional } \\
\text { irrigation }\end{array}$ & 1.089 & \multicolumn{2}{|c|}{ Side dressed } & & \multicolumn{2}{|c|}{ Side dressed } \\
\hline 0.6 Etc & 1.196 & 1.195 & 1.197 & 3230 & 3220 & 3240 \\
\hline 0.8 Etc & 1.640 & 1.638 & 1.642 & 3950 & 3930 & 3970 \\
\hline $1.0 \mathrm{Etc}$ & 1.423 & 1.420 & 1.427 & 4600 & 4570 & 4630 \\
\hline $1.2 \mathrm{Etc}$ & 1.620 & 1.619 & 1.622 & 5240 & 5200 & 5280 \\
\hline Mean & & 1.468 & 1.467 & & 4230 & 4280 \\
\hline \multicolumn{7}{|c|}{ Season 2010} \\
\hline $\begin{array}{l}\text { Conventional } \\
\text { irrigation }\end{array}$ & 0.843 & \multicolumn{2}{|c|}{ Side dressed } & 8410 & \multicolumn{2}{|c|}{ Side dressed } \\
\hline 0.6 Etc & 1.169 & 1.168 & 1.170 & 3630 & 3620 & 3640 \\
\hline 0.8 Etc & 1.493 & 1.366 & 1.620 & 4380 & 4340 & 4420 \\
\hline $1.0 \mathrm{Etc}$ & 1.342 & 1.286 & 1.399 & 5130 & 5070 & 5190 \\
\hline $1.2 \mathrm{Etc}$ & 1.218 & 1.213 & 1.222 & 6070 & 6040 & 6100 \\
\hline Mean & & 1.258 & 1.353 & & 4767 & 4837 \\
\hline
\end{tabular}

NS - not significant. 
for each irrigation treatment during season 2010 was relatively higher than that during season 2009. This could be attributed to the stressful weather conditions prevailing in season 2010 (higher evaporation demand in season 2010 than that in 2009) as shown in Table 1. Keeping in mind the average amount of water of the two seasons that had been supplied in treatment at 1.2 Etc $\left(5655 \mathrm{~m}^{3} \mathrm{ha}^{-1}\right)$ and the application of the fertilizer in $80 \%$ of irrigation time, which gave the best yield, it can be concluded that irrigation scheduling at 1.2 Etc with application of the fertilizer in $80 \%$ of irrigation time could save water by $27.2 \%$ and increase the grain yield by $6.7 \%$, compared to the conventional treatment.

The conventional irrigation treatment had the lowest water productivity (WP) $\left(0.966 \mathrm{~kg} \mathrm{~m}^{-3}\right)$, an average of the two seasons, compared with other irrigation scheduling and fertigation treatments in both growing seasons (Table 4). This is mainly due to the higher water amounts applied under the conventional irrigation than under the other treatments. The WP values under the irrigation and fertigation treatments ranged between 1.195 and $1.642 \mathrm{~kg} \mathrm{~m}^{-3}$ in the 1st season and from 1.168 to $1.620 \mathrm{~kg} \mathrm{~m}^{-3}$ in the 2 nd season. The highest value of WP $\left(1.631 \mathrm{~kg} \mathrm{~m}^{-3}\right)$ over the two seasons was recorded under the treatment at 0.8 Etc with fertigation application in $80 \%$ of the irrigation time. In turn, the lowest one $\left(1.181 \mathrm{~kg} \mathrm{~m}^{-3}\right)$ was recorded for the treatment at 0.6 Etc with the fertilizer applied in $60 \%$ of the irrigation time. These results indicate that the irrigation at an amount of 0.8 Etc and fertigation application in $80 \%$ of the application time is the best treatment under the condition of the studied area because it increased the WP of the maize crops by about $68.8 \%$, compared to the conventional method, and it allowed the application of less irrigation water for maize grain production. Similar results were obtained by Zwart and Bastiaansen (2004), who reported values of 1.1$2.7 \mathrm{~kg} \mathrm{~m}^{-3}$ for the WP of maize. These finding indicate that it is essential to employ appropriate methods for determining the amount of irrigation water and the period of applying the fertilizer through the irrigation water under the drip irrigation system.

\section{CONCLUSIONS}

1. Fertigation scheduling under the drip irrigation is more efficient than the conventional method for the maize crops in the sandy soil because it had higher water productivity than the conventional method.

2. In order to maximize maize yields and the productivity of the irrigation water under the drip irrigation system in the sandy soil, it is recommended to irrigate maize crops using a water amount at 1.2 of crop evapotranspiration every 3 days and applying the recommended fertilizer dose in $80 \%$ of the irrigation time.
3. Under water scarcity conditions, irrigation at 0.8 of crop evapotranspiration and application of fertigation in $80 \%$ of the irrigation time is recommended, since this treatment had the highest productivity of irrigation water $1.631 \mathrm{~kg} \mathrm{~m}^{-3}$ over the two seasons.

\section{REFERENCES}

AbdEl-Hafez S.A., El-Sabbagh A.A., El-Bably A.Z., and AbouAhmed E.I., 2001. Responses of maize crop to drip irrigation in clay soils. Alex. J. Agric. Res., 46(2), 153-159.

Abd El-Wahed M.H., and Ali E.A., 2013. Effects of irrigation system, amounts of irrigation water and mulching on corn yield, water use efficiency and net profit. Agric. Water Manag., 120(31), 64-71.

Abu-Zeid M., 1999. Egypt's Water Policy for the 21th Century, 7th Nile Conf., March 15-19, Cairo, Egypt.

Ali M.H., Hoque M.R., Hassan A.A., and Khair A., 2007. Effects of deficit irrigation on yield, water productivity,and economic returns of wheat. Agric. Water Manag., 92, 151-161

Allen R.G., Pereira L.S., Roes D., and Smith M., 1998. Crop evapotranspiration: guidelines for computing crop water requirements. FAO No. 56. Rome, FAO.

Deshmukh G. and Hardaha M.K., 2014. Effects of irrigation and fertigation scheduling under drip irrigation in papaya. J. Agric. Search., 1(4), 216-220.

Doorenbos J. and Kassam H.A., 1979. Yield response to water. FAO No. 33, Rome: FAO, 101-103.

El-Beltagy A.T. and Abo-Hadeed A.F., 2008. The main pillars of the national program for maximizing the water-use efficiency in the old land.The Research and Development Council, Ministry of Agriculture and Land Reclamation (MOALR), Giza, Egypt.

El-Gindy A.M., Abd El-Salam M.F., Abdel-Aziz A.A., and EI-Saha E.A., 2003. Some engineering properties of maize plants,ears and kernels under different irrigation systems. J. Agric. Sci. Mansura Univ., 28(6), 4339-4360.

El-Hendawy S.E., Hokam E.M., and Schmidhalter U., 2008. Drip irrigation frequency: the effects and their interaction with nitrogen fertilization on sandy soil water distribution, maize yield and water use efficiency under Egyptian conditions. J. Agron. Crop Sci., 194, 180-192.

El-Kalla S.E., El-Hindi M.H., Hanna A.S., and Ainer N.G., 1985. Maize growth, yield and yield Components and chemical composition of grains as affected by different irrigation levels and plant population. Agric. Res. Rev., 63(7), 167-176.

El-Meseery A.A., 2003. Effects of different drip irrigation systems on maize yield in sandy soil. 11th Annual Conf. Society Misr of Agriculture Engineering Role in Reducing Losses and Maximizing Production. Misr J. Ag., 576-594.

El-Nady M.A. and Borham T.I., 2009. Responses of corn yield to water deficit and rice straw mulch at some growth stage. Bulletin of Faculty of Agriculture, Cairo University, 60(2), $226-233$ 
Feleafel M.N. and Mirdad Z.M., 2013. Optimizing the nitrogen, phosphorus and potash fertigation rates and frequency for eggplant in arid regions. Int. J. Agric. Biol., 15(4), 737-742.

Lamm F.R., Trooien T.P., Manges H.L., and Sunderman H.D.,2001. Nitrogen fertilization for subsurface drip irrigated corn. Trans. ASAE, 44(3), 533-542.

Majumdar D.K., 2002. Irrigation Water Management: Principles and Practice. New Delhi: Prentice-Hall of India.

Moayeri M., Siadat H., Pazira E., Abbasi F., Kaveh F., and Oweis T.Y., 2011. Assessment of maize water productivity in southern parts of the Karkheh river basin, Iran. World Applied Sci. J., 13(7), 1586-1594.

Ne Smith D.S. and Ritchie J.T., 1992. Short and long term responses of corn to a pre anthesis soil water deficit. Agron. J., 84, 107-113.

Otegui M.E., Andrade F.H., and Suero E.E., 1995. Growth water use and kernel abortion of maize subjected to drought at silking. Field Crop Res., 40, 87-94.

Pandey R.K., Maranville J.W., and Admou A., 2000. Deficit irrigation and nitrogen effects on maize, in a sahlian environment, grain yield and yield components. Agri. Water Manag., 46, 1-13.
Papadopoulos I., 1995. Use oflabelled fertilizers in fertigation research. Proc. Int. Symp. Nuclear and Related Techniques in Soil/Plant Studies on Sustainable Agriculture and Environmental Preservation. P: 399-410 Vienna.

Steel R.G. and Torrie J.H., 1984. Principles and procedures of statistics. A Biometrical Approach. McGraw. Hill Book Company, New York, USA.

Stone P.J., Wilson D.R., Jamieson P.D., and Gillespie R.N., 2001. Water deficit effects on sweet corn I: water use, radiation use efficiency, growth, and yield. Aust. J. Agric. Res., 52, 103-113.

Tan K.H., 1996. Soil sampling, Preparation and Analysis. Marcel Dekker Press, New York, USA.

USDA, 2011. Grain: World markets and trade. Foreign Agriculture Service, Circular Series FG 09-11. Foreign Agricultural Service, United States Department of Agriculture, http:// www.fas.usda.gov/psdonline/circulars/grain.pdf

Vijayakumar G., Tamilmani D., and Selvaraj P.K., 2010. Irrigation and fertigation scheduling under drip irrigation in brinjal (Solanum melongena L.) crop. Int. J. Bio-res Management, 1(2), 72-76.

Zwart S.J. and Bastiaansen W.G.M., 2004. Review of measured crop water productivity values for irrigated wheat, rice, cotton and maize. J. Agric. Water Manag., 69, $115-133$ 